\title{
Rationale behind IPO Underpricing: Evidence from Asian REIT IPOs
}

\author{
Joseph T.L. Ooi, ${ }^{*}$ Masaki Mori** and Woei-Chyuan Wong***
}

This article examines the rationale behind IPO underpricing using a sample of REIT IPOs in Asia. Although the IPOs registered an average initial return of $3.08 \%$, the issuers were able to sell the IPO shares above their fundamental values by timing the listings in periods when existing REIT stocks are traded at a premium to their net asset values (NAV). An IPO could therefore be underpriced and yet produce a net gain for the issuer. The issuers' net gain from IPO is, however, negatively related to long-run performance of REIT IPOs.

\section{Introduction}

In the financial market, issuers face the challenge of establishing the right offer price for an initial public offering (IPO). One puzzling aspect is that IPOs are often underpriced, that is, their first day closing market price is higher than the offer price, by as much as $10-24 \% .{ }^{1}$ If the shares were sold at the first day closing price, the IPO proceeds would have been higher by an amount equal to the IPO underpricing, or the same proceeds could have been raised by selling fewer shares (Loughran and Ritter 2002). This puzzle stems from the difficulty of measuring the fundamental value of a new firm. The first-day closing market price is usually assumed to be the intrinsic value of the shares, but this might not necessarily be true in an inefficient market characterized by investors' heterogeneity and short sales constraints (Miller 1977, Daniel Hirshleifer and Subrahmanyam 1998, Ritter and Welch 2002, Derrien 2005).

In this article, we measure the fundamental value of a new firm using its net asset value (NAV), which represents the residual claims of shareholders in

*National University of Singapore or rstooitl@nus.edu.sg.

**National University of Singapore or rstmm@nus.edu.sg.

***Universiti Utara Malaysia or wwchyuan@uum.edu.my.

${ }^{1}$ See Rock (1986), Tinic (1988), Allen and Faulhaber (1989), Benveniste and Spindt (1989), Grinblatt and Hwang (1989), Habib and Ljungqvist (2001), Loughran and Ritter (2002), Lowry and Shu (2002), Ritter and Welch (2002), Derrien (2005), Ljungqvist (2008) and Liu and Ritter (2011). 
the event that the firm is liquidated after paying off all of its debts. The NAV valuation approach is more suited for firms owning tangible assets that have well-determined market prices, such as holding companies that invest in real estate assets. ${ }^{2}$ For this reason, we focus on the IPOs of real estate investment trusts (REITs), which are special investment entities set up for investing in and owning real estate assets. By regulation, at least $75 \%$ of a REIT's assets must be invested in tangible real estate. A REIT must also distribute at least $90 \%$ of its net income as dividends to its shareholders, making its dividend flow and growth rate more predictable. This reduces the role of asymmetric information, one of the most popular explanations for IPO underpricing. ${ }^{3}$ Our study focuses on IPOs of equity REITs listed on four stock exchanges in Asia, namely, Japan, Hong Kong, Singapore and Malaysia. The listing conditions in these markets specifically require issuers to report and substantiate a firm's NAV with independent valuation reports by professional appraisers. All REIT IPOs in these four countries also involved "specified assets"; that is, all of the properties that are to be injected into the REIT are identified in the prospectus together with their independent valuation reports. ${ }^{4}$

To our knowledge, our study is the first to formally analyze the relationship between REIT IPO pricing and NAV. In the first part of our empirical analysis, we examine the initial day returns, measured as the percentage change on the share price on their first trading day, of the sampled REIT IPOs to establish

\footnotetext{
${ }^{2}$ IRS Revenue Ruling 59-60, Section 5(b) stipulates that, "the value of the stock of a closely held investment or real estate holding company, whether or not family owned, is closely related to the value of the assets underlying the stock. For companies of this type, the appraiser should determine the fair market values of the assets of the company... adjusted net worth should be accorded greater weight in valuing the stock of a closely held investment or real estate holding company, whether or not family owned, than any other customary yardsticks of appraisal, such as earnings and dividend paying capacity." Source: National Association of Certified Valuators and Analysts (NACVA, 2012).

${ }^{3}$ The asymmetric information explanation posits that one player in the IPO process is better informed than the others (Allen and Faulhaber 1989, Grinblatt and Hwang 1989) and that large first-day returns can be interpreted as compensation to uninformed investors for bearing such risks (Rock 1986) or as remuneration to informed investors for providing private information about the true value of the stock during the premarketing or book-building exercise (Benveniste and Spindt 1989). However, Ritter and Welch (2002) conclude that these asymmetric information models have been overemphasized.

${ }^{4}$ In the United States, it is possible to list "blind pool" REITs; that is, the property assets need not be identified in the prospectus. A "blind pool" REIT IPO usually includes only an audited "balance sheet" of the new REIT. The capital raised will be invested after the offering at the discretion of the sponsor pursuant to a predefined investment strategy as outlined in the prospectus. For more information, see PricewaterhouseCoopers (December 2011) "Roadmap for a REIT IPO-A Summary Guide to Going Public."
} 
Figure 1 - Distribution of IPO pricing. This figure summarizes the distribution of the average IPO pricing based on sample means. Panel A shows the total gain from the average IPO, which is measured as the difference between first-day closing price (C) and NAV per share (A). The portion of the gain between B and A represents the net gain for the firm from IPO, while the portion of the gain between $\mathrm{C}$ and $\mathrm{B}$ represents IPO underpricing. Panel B shows the issuer's IPO filing range; the floor price (D) and the ceiling price (E), relative to the NAV (A). NAV* $(F)$ represents the expected price level based on the prevailing peer-NAV premiums at the time of issue and is defined as the NAV of IPO REIT multiplied by (one plus peer-NAV premium) in which the peer-NAV premium is the median NAV premium among peers (all REITs within the same country) at the time of the IPO. [Color figure can be viewed at wileyonlinelibrary.com]
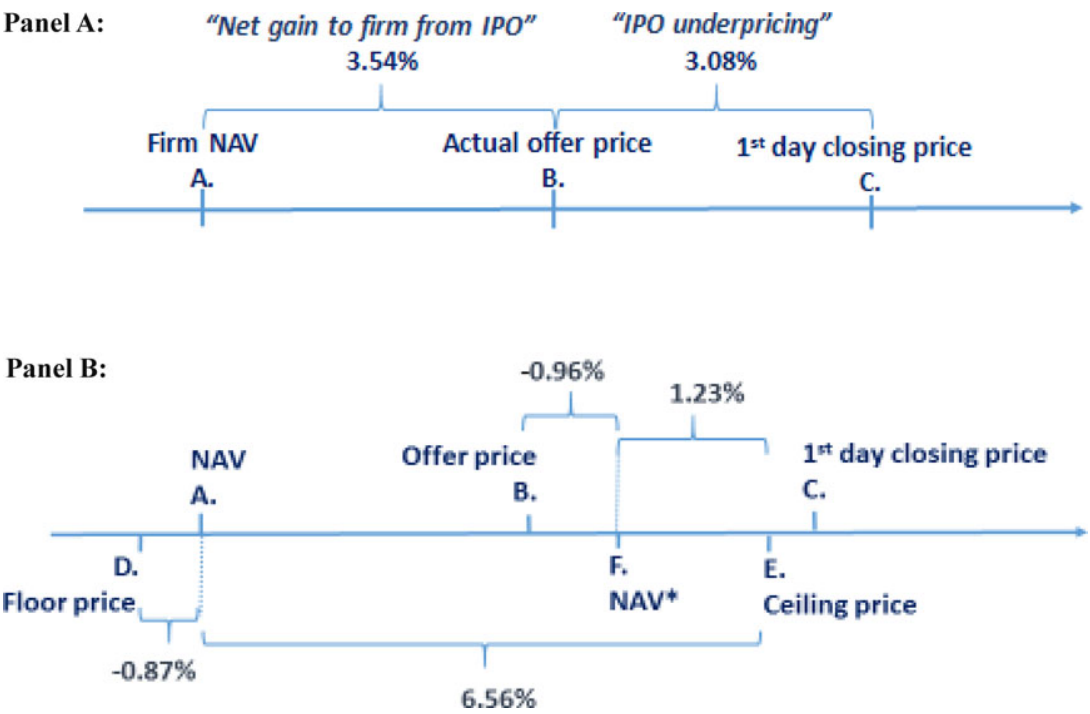

that underpricing is indeed evident with REIT IPOs. We then compare the offer price with the fundamental value of the shares, measured by NAV. If the offer price/NAV ratio of the shares is less than one, the issuers can be inferred to have experienced a net loss from the public listing. However, if the offer price/NAV ratio exceeds unity, the issuers have enjoyed a net gain from the IPO.

The results are summarized in Panel A of Figure 1, which illustrates how an underpriced IPO could still produce a net gain for the issuers. The difference between the first-day closing price (C) and the NAV of the shares (A) times the total number of shares represents the total gains from IPO. It reflects the issuer's ability to obtain a higher valuation on its real estate portfolio by opting for a public listing as opposed to selling the assets in the parallel private real estate market. REIT IPOs, similar to closed-end fund (CEF) IPOs 
traded on major stock exchanges, transform illiquid assets into liquid assets. ${ }^{5}$ On the basis that the discount rate for liquid assets should be lower than that for the underlying illiquid assets, Cherkes, Sagi and Stanton (2009) argue that a REIT could sell at a premium to NAV in equilibrium. ${ }^{6}$

The net gains from the IPO are shared between the issuer and investors with the proportion based on the final offer price. The initial return of the average REIT IPO is $3.08 \%{ }^{7}$ which is much lower than the initial returns recorded by operating company IPOs. This is not unexpected, because REITs are more transparent and easier to value than general firms. ${ }^{8}$ More interestingly, Panel A of Figure 1 also shows that the offer price of the shares (B) is on average $3.54 \%$ higher than their NAV (A). This difference, which represents the net gain to the firm from IPO (vs. staying private), provides a rationale for issuers and their underwriters to set the offer price below the first-day closing price. The observation that a REIT IPO could be underpriced and yet produce a net gain for the issuer is a new contribution to the literature.

In practice, most IPOs engage in a book-building exercise during which institutional and large investors are invited to register their interests based on a preliminary price range filed by the underwriters. ${ }^{9}$ In the context of a REIT going public, there are two potential reference points for the underwriters to anchor the IPO price range. As postulated earlier, the firm's NAV is an important reference point to compute IPO gains (or losses), because the issuer could sell the physical assets in the alternative private real estate market at their full market value (Chan, Wang and Yang 2009). Another reference point for IPO

\footnotetext{
${ }^{5}$ We thank Jay Ritter for highlighting this. Clayton and MacKinnon (2000) also highlight that a major difference between CEFs and REITs is the relative degree of difference in the liquidity of fund units (or shares) and the assets that CEFs or REITs hold. Specifically, real estate assets owned by REITs tend to be less liquid than the securities held by CEFs.
}

${ }^{6}$ However, the present value of the management fees would offset part or all of the liquidity transformation strategy. Ooi (2009) observes that the average compensation of REIT managers in Singapore is approximately $0.54 \%$ of the assets under management (AUM).

${ }^{7}$ The amount of money on the table is equal to the price increase on the first day of trading times the total number of shares issued. Note that the issuer also receives part of the money left on the table in proportion to the number of shares retained by the issuer.

${ }^{8}$ Other studies that examine the pricing of REIT IPOs also recorded first day returns that are generally much lower than those observed for common IPOs (Wang, Chan and Gau 1992, Below, Zaman and McIntosh 1995, Ling and Ryngaert 1997, Brounen and Eichholtz 2002, Wong, Ong and Ooi 2013).

${ }^{9}$ Benveniste and Spindt (1989) provide a good discussion on the premarketing activities involved in an IPO. 
underwriters to consider would be the firm's NAV adjusted by the prevailing peer-NAV premiums (we define this as $\mathrm{NAV}^{*}$ ), which incorporates additional information about the prevailing market premium/discount on NAVs around the time of filing the preliminary price range. To gain additional insights into how REIT IPOs are priced, we further analyze the preliminary price range, namely, the floor price and the ceiling price, filed by the underwriters relative to the share's NAV as well as NAV*.

Panel B of Figure 1 shows that the difference between the NAV (A) and the floor price (D) of the filing range is small $(-0.87 \%)$ and statistically insignificant, suggesting that the reserve price of the IPO shares is pegged close to their intrinsic value. The issuers' reluctance to register a net loss from IPO by transferring their assets to the newly listed REITs at below their market value is logical because the properties could be sold directly, either individually or as a portfolio, to other investors, including existing publicly traded REITs (Chan, Wang and Yang 2009). The ceiling price (E) of the filing range, on the other hand, is set well above $(6.56 \%)$ the firm NAV. It is, however, only slightly above $\mathrm{NAV}^{*}(\mathrm{~F})(1.23 \%$, not statistically significant). The final offer price is also close to $\mathrm{NAV}^{*}(-0.96 \%$, statistically insignificant). These observations combined suggest that underwriters are firstly careful to avoid any missed opportunity due to filing a too low ceiling price and, second, information contained in the NAV premiums of existing publicly traded REITs is incorporated into the IPO preliminary distribution price and offer price.

In the second part of the empirical analysis, we examine how IPO pricing is affected by market condition and large investors' reception during the roadshow. The underwriters, by timing the listings to coincide with favorable conditions in the stock market, seek to price the IPO stocks above their intrinsic value to generate a net gain for the issuers. The underwriters also gather useful information during the roadshow which could be used to determine the final offer price and allocation of the IPO. As shown in Figure 2, we find that REITs tend to go public during periods when the stock prices of their peers are at a premium to NAV because the bullish valuation in the capital market, which is when underlying assets are more highly valued in the capital market than in the private market, allows issuers to price the new shares above their NAVs. This market-timing behavior is consistent with the "windows of opportunity" hypothesis whereby firms take advantage of transitory windows by issuing equity offerings when their stocks are substantially higher than the fundamental value of their underlying assets (Loughran and Ritter 1995, Buttimer, Hyland and Sanders 2005; Boudry, Kallberg and Liu 2010).

In the third part of our empirical study, we examine the possible effects of pricing the IPO stocks above their fundamental value on their initial day 
Figure 2 a Price/NAV premium of REITs (Jan 2002-Dec 2014). Chart A tracks the monthly NAV premium (closing price/NAV per share) and the volume of Asian REIT IPOs between 2002 and 2014. The vertical axis on the left-hand side represents the total number of IPOs in the corresponding month, whereas the vertical axis on the right-hand side represents the median NAV premium. Chart B tracks the yearly NAV premium and the volume of all Asian IPOs (not just REITs) between 2002 and 2014 in each of the four Asian stock markets. The vertical axis on the left-hand side (bar chart) represents the total number of IPOs in the corresponding year (by country), whereas the vertical axis on the right-hand side represents the median NAV premium. [Color figure can be viewed at wileyonlinelibrary.com]

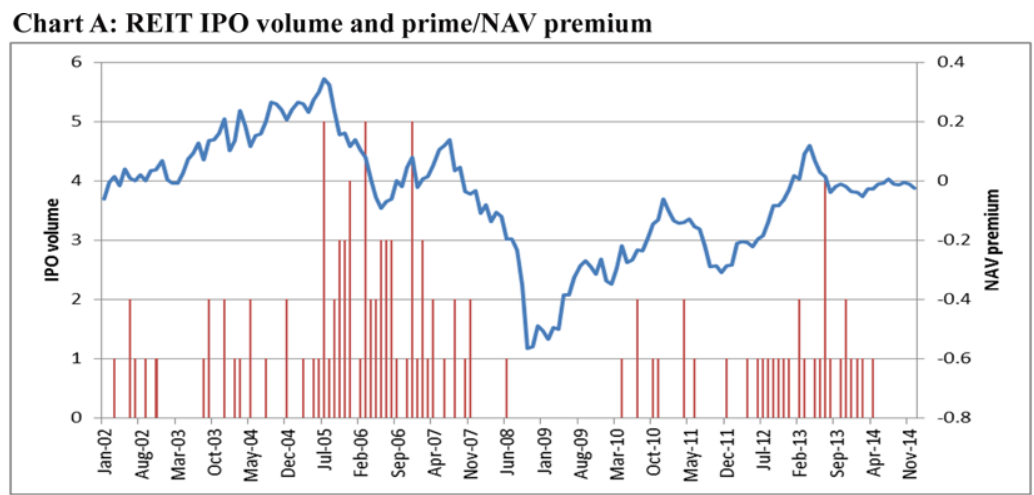

Chart B: Asian IPO volume and prime/NAV premium

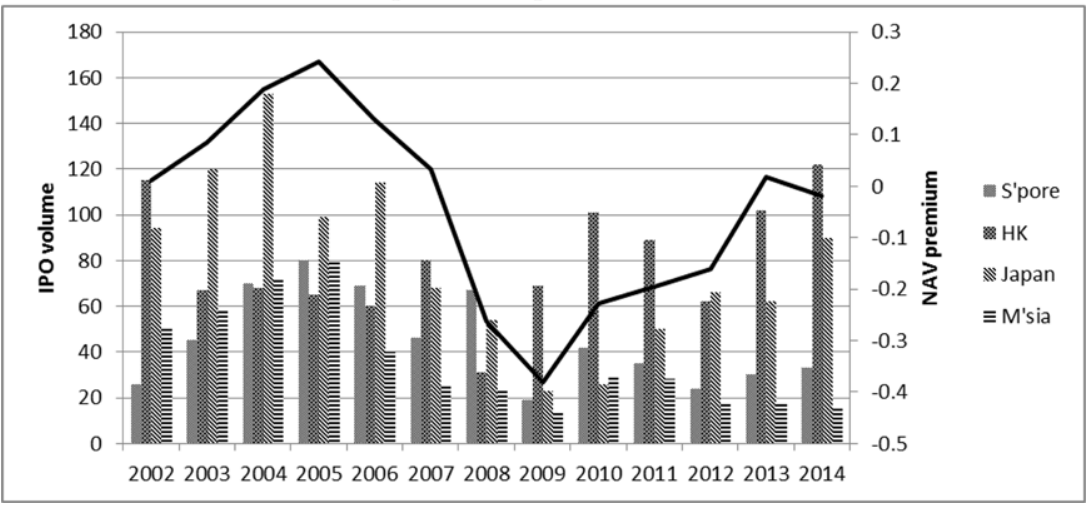

return and long-run performance (over 100-day, one-year and three-year holding periods). Due to the market-timing behavior of issuers, we expect that the initial day return is correlated with the issuer's net gain and that the stock price will revert to its fundamental level over a longer period. We test these propositions by examining whether the initial day return and long-run performance of REIT IPOs are related to issuers pricing the IPO stocks above 
their fundamental value by timing the IPO during bullish valuation in the capital market. As predicted, we find that issuers' net gain is positively related to the initial day returns and negatively to firm performance over longer horizons.

In summary, the findings suggest that the average REIT IPO is able to create wealth for both the investors and the issuer in the short run, but it underperforms over longer horizons as the bullish stock price readjusts back to its fundamental level. Conversely, we find that the offer price premium over $\mathrm{NAV}^{*}$ is not significantly related to the initial day returns, suggesting that underwriters have incorporated information contained in the prevailing market premium when setting the offer prices. The long-run performance of the REIT IPOs are, however, positively related to the offer price premium over $\mathrm{NAV}^{*}$, which is not surprising, as REITs that hold high-quality properties and or have better growth prospects are expected to have superior long-run performance over their peers.

Our article proceeds as follows. The "Why REITs" section provides the relevant institutional background on REITs. The "Data" section describes the data employed. The "Results" section contains the empirical results. The last section provides our conclusions.

\section{Why REITs}

REITs are special investment entities set up to invest in and own real estate assets collectively. To qualify as a REIT, a firm must meet several requirements. First, at least $75 \%$ of its total assets must be in real estate. Second, a significant portion of its gross income must come from real estate-related sources, such as rents. Third, it must pay out a significant portion (at least $90 \%$ ) of its taxable income as dividends. As an investment vehicle, a REIT enjoys tax transparency status, meaning that it is not subject to corporate income tax. Thus, there is no tax advantage for a REIT to have debt in its capital structure (see Ooi, Ong and Li 2010).

Essentially, two approaches exist to determine the true value of stocks. The most common method for valuing firms going public is to use comparable firm multiples. ${ }^{10}$ However, Ritter and Welch (2002) warn that the accounting data of newly listed firms might not be reliable because they are usually valued on

\footnotetext{
${ }^{10}$ Studies that have employed comparable firm multiples to estimate the fundamental value of IPO firms include Purnanandam and Swaminathan (2004), Pukthuanthong-Le and Varaiya (2007), Jagannathan and Gao (2004) and Campbell et al. (2008).
} 
the basis of their growth options. ${ }^{11}$ In contrast, the NAV valuation approach involves determining the fair market value of the assets owned by a firm. This approach may not be easily employed to value firms that carry their assets on the balance sheet at historical cost (less accumulated depreciation). To revise the NAV of these firms, a stock analyst adjusts the book value of the assets to their fair market value, typically by applying broad assumptions and desktop calculations. Furthermore, the estimation of a firm's asset value is complicated by the presence of intangible assets, such as trademarks, patents, goodwill, or alliances. Nonetheless, the relatively straightforward nature of property assets has led many stock analysts to value REITs by their underlying asset holdings (Capozza and Seguin 2003, Gentry, Jones and Mayer 2003). Gentry, Jones and Mayer (2004) propose that REITs' price/NAV ratios are more reliable than those of operating firms, because they are backed by property appraisals, which involve a physical inspection of each assessed property by independent appraisers who are specialists in their field.

Another advantage of using data from a single industry, and on REITs in particular, is the reduction of potentially confounding effects attributable to differences in risk, transparency and growth potential (Hartzell, Kallberg and Liu 2005). REITs are more homogenous, because they hold real assets and face similar growth constraints. Therefore, they can be viewed as good peers for valuation purposes (Chan, Chen and Wang 2013). Hartzell, Kallberg and Liu (2008) find that REIT IPOs exhibit lower prediction errors (19\%) relative to IPOs of general firms (40\%). This leads them to conclude that REITs are relatively easy to value, even using simple comparables, because they exhibit less cross-sectional variations in pricing. ${ }^{12}$

Given the dual markets for real estate assets, REITs also provide a good laboratory for tracking how real estate stocks could deviate from their fundamental values in the private real estate market. Analyzing a sample of U.S. REITs that traded during the period of 1990-2003, Gentry, Jones and Mayer (2004) note that, although the median price/NAV ratio was 1.01 , it varies significantly over time. Specifically, the median value increased to higher than 1.20

\footnotetext{
${ }^{11}$ The dividend capitalization model can be further simplified if a constant growth rate $\mathrm{g}$ is assumed over an infinite time horizon and if the discount rate $k$ is greater than the growth rate $g$. This result is the familiar Gordon dividend discount model, where $P_{0}$ $=D /(k-g)$, where $D$ is dividend per share. Ritter and Welch (2002) highlight that the prior rapid growth of many young companies makes it easy to justify high valuations by investors who want to believe that they have identified the next Microsoft.
}

${ }^{12}$ Hartzell, Kallberg and Liu (2008) compare a rough estimate of prediction errors for REIT IPO pricing to that documented by Kim and Ritter (1999) for general corporations. Using the median Q for all seasoned REITs to predict a REIT IPO's Q, their mean absolute prediction error is less than half as large as that in Kim and Ritter. 
for all of 1997 and decreased to lower than 0.90 for most of $2000 .{ }^{13}$ Clayton and MacKinnon (2000) further attribute the variations over time to changing investment sentiment in the REIT market. ${ }^{14}$ Linking the price/NAV ratio to REIT capital structure decisions, Boudry, Kallberg and Liu (2010) find that REITs are more likely to issue equity when their price/NAV is trading higher than one, which generally coincides with the capital market valuing the cash flows of the underlying property portfolio more highly than the private market. During these periods, the cost of equity in the public market is relatively cheaper than that in the private market. Ling, Ooi and Xu (2016) examine the impact of asset growth rates on the future stock performance of 308 publicly traded REITs and find evidence that the growth effect is significantly less negative for REITs selling at a premium to NAV. ${ }^{15}$

\section{Data}

Our study sample covers all REIT IPOs listed between 2001 and 2013 on four stock exchanges in Asia, namely, Japan, Singapore, Hong Kong and Malaysia. All REITs in these countries are equity REITs (that is, there are no mortgage REITs or hybrid REITs). It should be noted that Asian REITs are relatively new. The first two REITs in Japan were listed in September 2001, followed by Singapore's maiden REIT listing in 2002. In 2005, REIT markets took off in Hong Kong and Malaysia. Table A1 in the Appendix provides a comparison of the REIT structures in these four markets. The guidelines in these markets are generally similar, but to account for possible differences across markets, we compute IPO volume, peer pricing and market performance using information for the respective markets.

\footnotetext{
${ }^{13}$ Several studies have also investigated the equilibrium relationship between the NAV and market capitalizations of non U.S. REITs. Barkham and Ward (1999) find that U.K. property stocks trade, in general, at a discount to their NAV. Patel, Pereira and Zavodov (2009) report a tendency for the NAV discount of U.K. REITs to revert to the long-term mean value of 20\%. While Liow (2003) also finds some evidence of mean reversion behavior of Singapore property stocks towards their NAV, he notes that the speed of reversion is slow and deviations between the two markets' valuation could therefore be prolonged.
}

\footnotetext{
${ }^{14}$ Recent studies in behavioral finance present evidence that investor sentiment has a significant impact on stock prices. Lee, Shleifer and Thaler (1991) attribute the divergence of the stock price from the NAV of closed-end funds to investor sentiment. Baker and Wurgler (2006) attribute stock mispricing to an uninformed demand shock in the presence of a binding arbitrage constraint.

${ }^{15}$ Ling, Ooi and $\mathrm{Xu}$ (2016) highlight the existence of a parallel private market that allows a listed REIT to potentially arbitrate its observed cost of capital advantage or disadvantage. More specifically, a REIT can permanently increase its NAV and create shareholder value by funding asset growth when NAV premiums are positive and by buying back stock or paying off debt with the proceeds from the sale of properties when its stock is selling at a discount to NAV.
} 
Table 1 shows the fluctuating number of REIT IPO issues during the 13-year study period that spans different market cycles: 2001-2004 coincided with a slow market, whereas 2005-2007 marked the hottest IPO wave, with a total of 60 offerings. The number of IPOs dried up in 2008-2009 primarily because of the global financial crisis, which saw many IPO sponsors postponing their listing plans. ${ }^{16}$ The number of IPOs started to increase again in 2012.

Our initial sample covers 112 equity REIT IPOs. Two IPOs had to be omitted from the study sample because of missing data. Another three IPOs (CapitaLand Commercial Trust, Ascott Residence Trust and K-REIT Asia) involved spin-offs-events during which shares of new firms are distributed (either freely or at a heavily discounted price) to existing shareholders of issuing firms-and were also omitted. ${ }^{17}$ The final sample of 107 IPOs covered $94 \%$ of the total listed REITs in Asia based on their market value. Data on the IPOs, financial attributes and REIT performances during the study period were extracted from Bloomberg. Information on the stock ownership of sponsors and institutional investors was hand collected from the listing prospectus. Information on the NAV per share, which is defined as the REIT's total assets minus total liabilities scaled by total shares outstanding after the IPO, are extracted from the IPO prospectus for Hong Kong, Malaysia and Singapore REITs and from the financial statements of Japanese REITs. In contrast, U.S. REITs are not required to report the appraised value of their properties; therefore, their NAVs are not directly observed. ${ }^{18}$

All of the sampled REIT IPOs engage in a book-building exercise during which institutional investors are invited to register their interest. ${ }^{19}$ The underwriter first estimates an offer price range for the shares, and then conducts

\footnotetext{
${ }^{16}$ The following eight REIT IPOs were pulled: Sunlight REIT (May 2006), Regal REIT (September 2006), AIG J-REIT (November 2007), Dynasty REIT (October 2012), SPH REIT (May 2013), Lotte Shopping REIT (February 2014), Manulife U.S. REIT (June 2015) and APL Japan Trust (October 2017). The main reason for pulling these IPOs is the deterioration in the capital market that would adversely affect the IPO offer price and take-up rate. In most instances, the market NAV premium declined during the premarketing period.
}

${ }^{17}$ Note that all REITs in these four countries are equity REITs. Mortgage REITs and hybrid REITs do not exist. Additionally, all of the IPOs of these REITs involved specified assets. Thus, we did not exclude any REIT IPOs except for those with missing data and those that were spin-offs.

\footnotetext{
${ }^{18}$ Reliable NAVs are not widely available for seasoned U.S. REITs because their real estate assets are not always marked to market value (Barkham and Ward 1999, Clayton and MacKinnon 2000).
}

${ }^{19}$ Since its introduction, the book-building IPO procedure has dominated IPO auctions in both the United States and globally, despite strong economic incentives in favor of auctions. Degeorge, Derrien and Womack (2007) hypothesize that corporate issuers and investment banks are in a quid pro quo relationship; that is, issuers are willing 


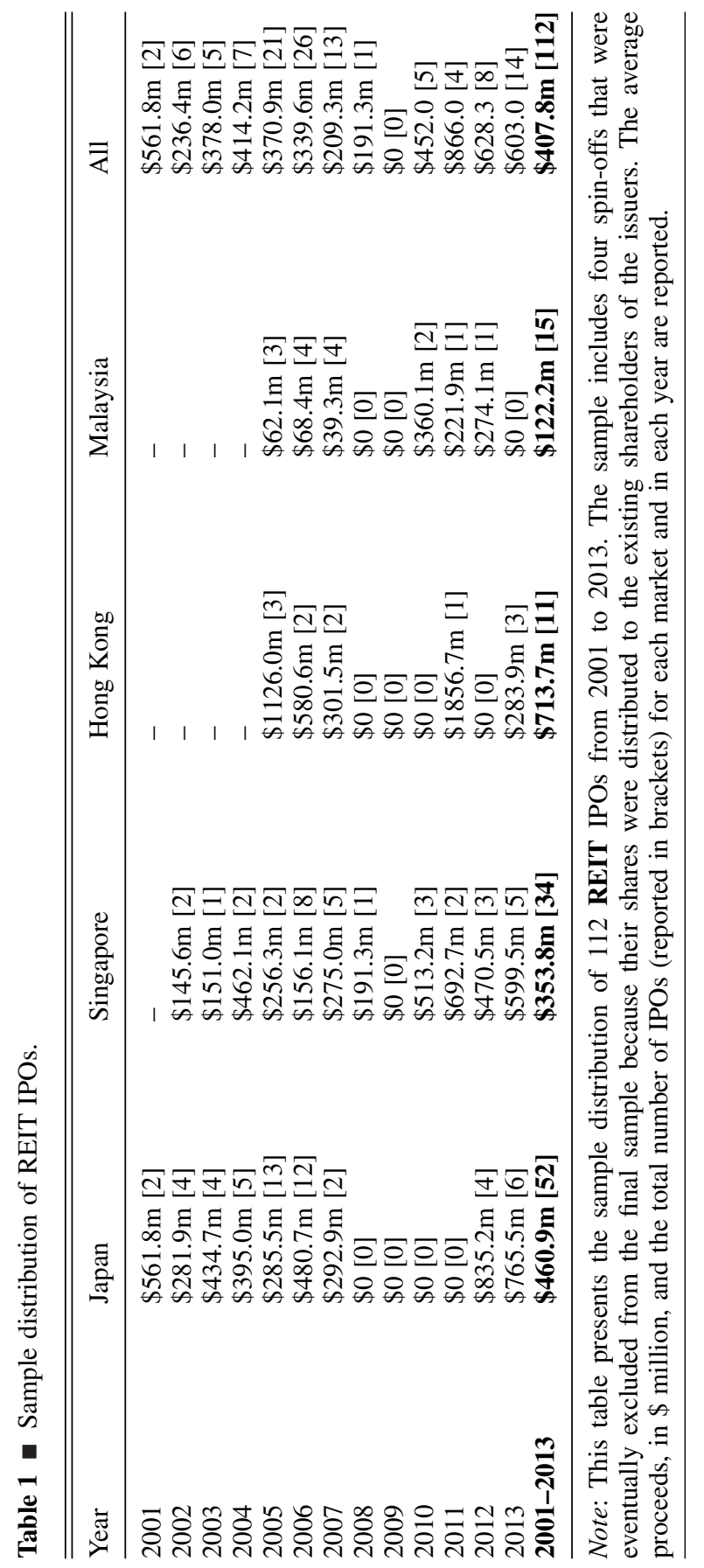


a "roadshow" to gauge the market's reception to the issue. The roadshow is designed by the issuer to both inform and educate investors and to solicit information about the market's reception to the issue. For example, investors might express mild or strong interest at different prices within the underwriter's proposed range. The nonbinding indication of interest is used to set the final offer price, which may fall anywhere within the lower and upper bound of the price range depending on the information extracted from investors during the roadshow (Benveniste and Spindt 1989). The overallotment option is normally exercised when premarket demand for the shares exceeds expectations. ${ }^{20}$

For 93 of the IPOs, we were able to obtain the preliminary price range filed by the underwriters for the roadshow. All IPOs were eventually priced within the price range. The ceiling price of the IPO filing range reflects the issuer's optimism, and the floor price reflects the issuer's reserve price, or the minimum price for the IPO to proceed. In practice, the final offer price is dictated by the market's reception during the roadshow. If the IPO is well received, the final offer price is likely to be fixed at the upper range of the filing price. However, if the response is lukewarm, the final offer price is likely to fall toward the lower range of the filing price. In our analysis, the popularity of an IPO stock is gauged by the percentage difference between the final offer price and the midpoint of the filling range. Of our sampled REIT IPOs, $69.9 \%$ were eventually priced at or higher than the midpoint price range, with $64.5 \%$ achieving the maximum filing price. The remaining $30.1 \%$ were eventually priced lower than the midpoint price range, with $18.3 \%$ fixed at the bottom of the price range.

\section{Results}

\section{Distribution of IPO Pricing}

We first examine the initial day returns (1st day close/offer price - 1) of the sampled IPOs to determine whether IPO underpricing exists with REIT IPOs. The traditional asymmetric information-based explanation for IPO underpricing views underpricing as a result of uncertainty regarding the true market value of the new entity (Rock 1986). Ritter and Welch (2002)

to pay the higher direct and indirect costs of book-building in exchange for increased and more favorable research coverage.

\footnotetext{
${ }^{20}$ In general, an overallotment option allows underwriters to issue as many as $15 \%$ more shares than originally planned. This option is also known as the "green shoe," after the name of the Green Shoe Manufacturing Company, which was the first to use the clause in its underwriting agreement.
} 
argue that IPO underpricing disappears entirely when information asymmetry approaches zero. ${ }^{21}$ To understand issuers' rationale behind the IPO underpricing, we examine whether the IPOs are priced lower than the fundamental value of the shares by comparing the offer price with its NAV. The offer price premium to NAV (Offer price/NAV - 1) indicates if issuing firms enjoyed net gains from IPOs. We further analyze the preliminary price range, namely, the floor price and the ceiling price relative to the firm NAV. In addition, we compare the first-day closing price with the ceiling price to examine if there is a missed opportunity by setting a too-low ceiling price.

Table 2 reports the distribution statistics for the IPO pricing of REITs listed between 2001 and 2013. We observe a statistically significant positive firstday return averaging $3.08 \%$, which is comparable to the $3.60 \%$ registered by 85 U.S. REIT IPOs from 1991 to 1994 (Ling and Ryngaert 1997). However, the first-day returns are much lower than those observed for general stock IPOs in Asian countries: $44.7 \%$ in Japan, $15.8 \%$ in Hong Kong, 25.8\% in Singapore and $56.2 \%$ in Malaysia (Loughran, Ritter and Rydqvist 2017). ${ }^{22}$ The smaller degree of IPO underpricing for REIT IPOs indicates that there is greater certainty over the fundamental values of REITs, which is not surprising, because REITs operate under more stringent rules to protect retail investors. Moreover, REITs own tangible real estate assets, which are not firm specific.

More interestingly, Table 2 shows that the offer price of the stock is, on average, $3.54 \%$ higher than its NAV. The median value of $3.63 \%$ is also statistically significant. Panel B further shows that the offer price is equal to or higher than NAV with $75.7 \%$ of REIT IPOs in our sample. Figure 1, which illustrates the relationship among the first-day closing price, the offer price and NAV, suggests that issuers can rationalize setting the offer price below the first-day closing price (IPO underpricing), since the offer price is still greater than the expected net sale price if the assets were sold in the private market. Note that, in our sample, issuing fees for the average REIT IPO amount to $2.47 \%$ of NAV or $3.17 \%$ of the proceeds. Even after subtracting fees, the premium ((Offer price-fees)/NAV -1$)$ is positive $(0.27 \%)$. Considering that selling assets in private market would require the total cost of approximately

\footnotetext{
${ }^{21}$ Empirical support for this prediction is provided by an early study by Peavy (1990), who observes that the mean initial days' return of 41 closed-end fund (CEF) IPOs in the 1980s was not significantly different from zero.

${ }^{22}$ Loughran, Ritter and Rydqvist (2017) is available on Jay Ritter's Web site (http://bear.cba.ufl.edu/ritter/ipodata.htm). Initial returns of U.S. REIT IPOs are also much lower than those of general IPOs, which averaged 17.9\% during 1980-2016.
} 


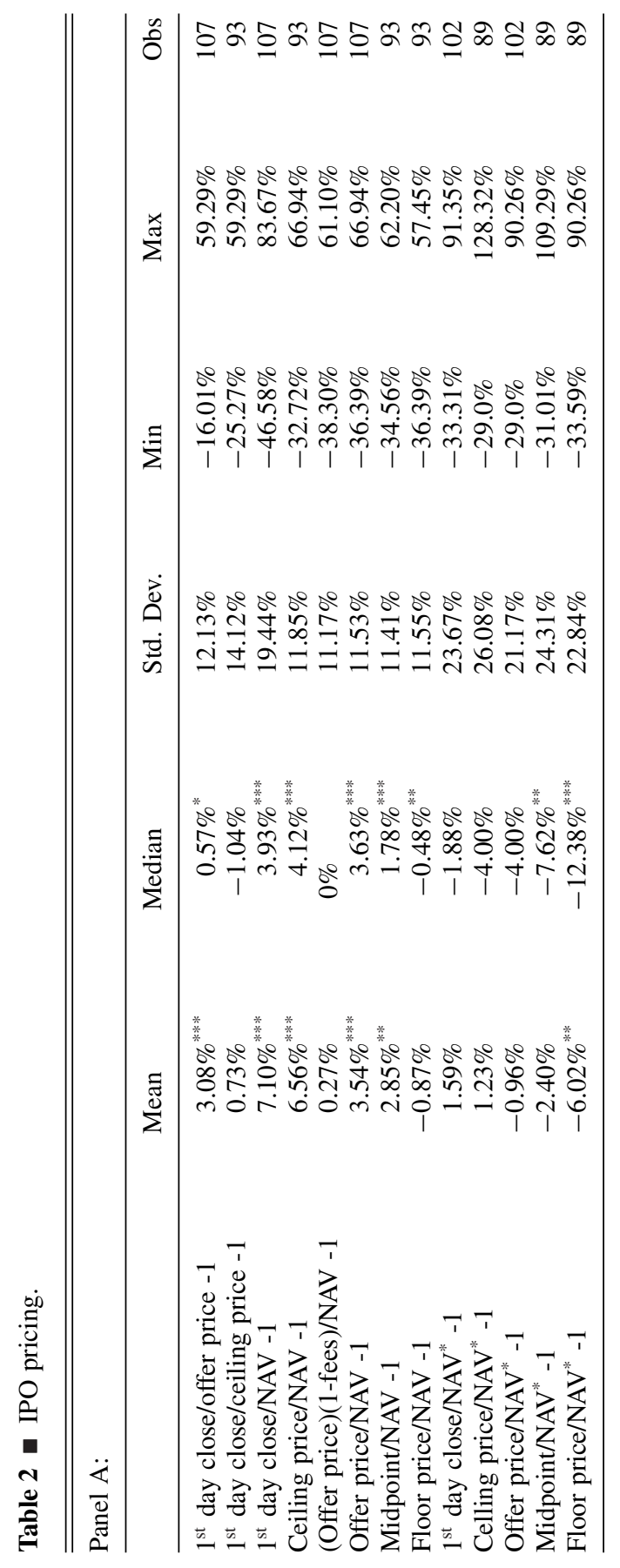




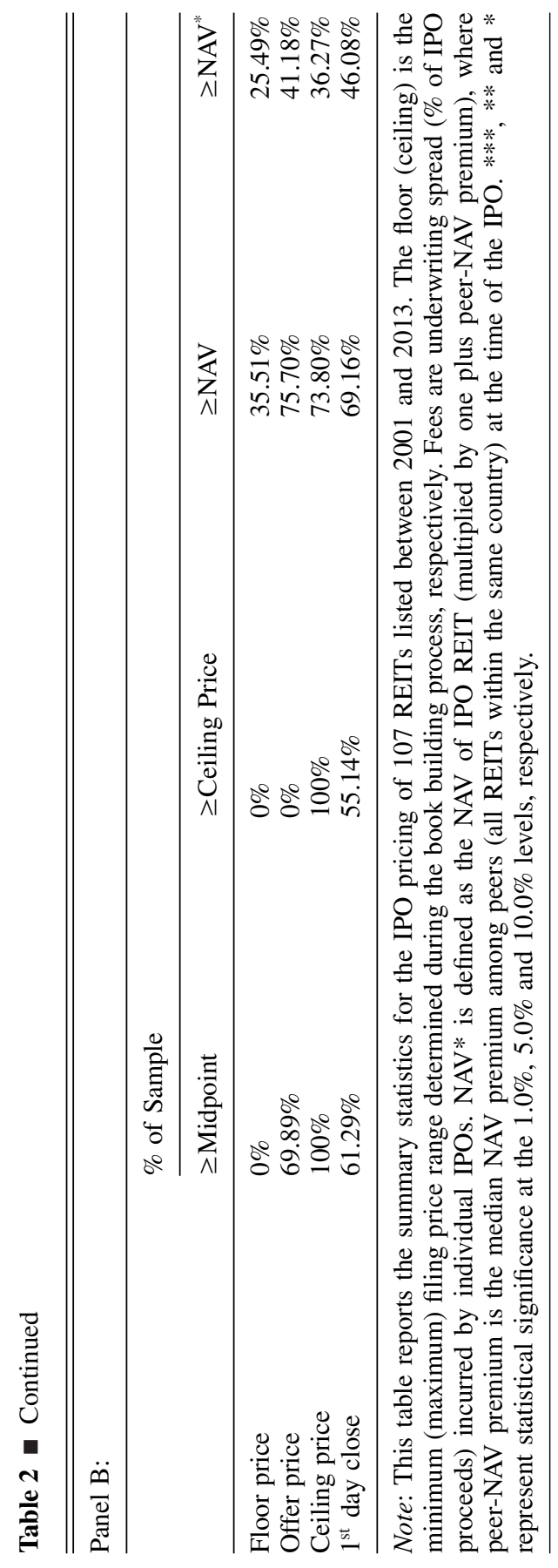


5\% in Asian countries, issuers were generally able to achieve net gains by going public even after fees are considered. ${ }^{23}$

We next analyze the preliminary price range, namely, the floor price and the ceiling price, relative to the firm NAV. The minimum price that is acceptable to an issuer can be extracted from the floor price of the filing range. Because the underlying property assets could be sold in the parallel private market, issuers have little economic incentive to proceed with an IPO unless they can obtain better pricing in the securitized market. In support, Table 2 shows that the reserve price of the shares, the floor price, is pegged close $(-0.87 \%)$ to their intrinsic value (NAV). The ceiling price, on the other hand, is set well above $(6.56 \%)$ the firm NAV and very close to the first-day closing price. On average, the ceiling price is only slightly below $(0.73 \%)$ the first-day closing price, and the difference is not statistically significant. This implies that the ceiling price is generally set high enough to prevent any missed opportunity for issuing firms.

To understand if the information about the market premium at the time of issue is incorporated into the IPO pricing, we compare the first-day closing price with the price level that would have been expected based on prevailing peer-NAV premiums at the time of issue. Specifically, we calculate NAV*, defined as the NAV of IPO REIT multiplied by (one plus peer-NAV premium) where peer-NAV premium is the median NAV premium among peers (all REITs within the same country) at the time of IPO. Table 2 shows that the average first-day closing price is not significantly higher than NAV* (1.59\%), indicating that underwriters do take into consideration the market premium of existing publicly traded REITs when setting the price range of the IPO.

\section{Effects of Market Condition and Market Reception on IPO Pricing}

To examine the effect of market conditions on IPO pricing, we separate the IPOs into offerings made in hot, normal and cold issue markets defined using the IPO volume in the general stock market (not just REITs) in each country. Following Lowry (2003), we classify periods at the top quartile of IPO volume in the respective markets as hot IPO markets and those at the bottom quartile as cold IPO markets. In addition to the prevailing market condition, a particular IPO might also be popular during the premarket exercise because of factors such as confidence in management, a good corporate

\footnotetext{
${ }^{23}$ The total cost of transferring properties in the direct market is approximately $5 \%$, which covers the brokerage fees, legal costs and stamp duties. Between 2005 and 2015, a tax concession was given to Singapore REITs that made them exempt from the normal 3\% stamp duty on acquisitions of local properties.
} 
Table 3 — Effects of market condition and market reception on IPO pricing.

\begin{tabular}{|c|c|c|c|c|c|}
\hline & {$[1]$} & Normal & Cold & $\begin{array}{l}{[4]} \\
\text { Popular } \\
\text { IPOs }\end{array}$ & $\begin{array}{l}{[5]} \\
\text { Unpopular } \\
\text { IPOs }\end{array}$ \\
\hline \multicolumn{6}{|l|}{ IPO Pricing } \\
\hline $1^{\text {st }}$ day close/offer price - 1 & $4.68 \%$ & $3.18 \%$ & $-1.33 \%$ & $6.89 \%$ & $-4.09 \%$ \\
\hline $1^{\text {st }}$ day close/ceiling price - 1 & $-0.11 \%$ & $1.46 \%$ & $-4.13 \%$ & $6.57 \%$ & $-10.42 \%$ \\
\hline $1^{\text {st }}$ day close/NAV - 1 & $10.44 \%$ & $7.0 \%$ & $1.06 \%$ & $14.63 \%$ & $-5.87 \%$ \\
\hline Ceiling price/NAV - 1 & $7.94 \%$ & $6.44 \%$ & $5.06 \%$ & $7.43 \%$ & $4.90 \%$ \\
\hline (Offer price)(1-fees)/NAV - 1 & $1.41 \%$ & $0.17 \%$ & $-3.50 \%$ & $3.39 \%$ & $-5.13 \%$ \\
\hline Offer price/NAV -1 & $4.84 \%$ & $3.44 \%$ & $1.76 \%$ & $7.08 \%$ & $-2.16 \%$ \\
\hline Midpoint/NAV -1 & $3.61 \%$ & $2.89 \%$ & $0.99 \%$ & $3.99 \%$ & $0.67 \%$ \\
\hline Floor price/NAV -1 & $-0.71 \%$ & $-0.65 \%$ & $-3.08 \%$ & $0.54 \%$ & $-3.57 \%$ \\
\hline $1^{\text {st }}$ day close $/ \mathrm{NAV}^{*}-1$ & $2.39 \%$ & $1.12 \%$ & $5.17 \%$ & $-0.50 \%$ & $3.38 \%$ \\
\hline Celling price/NAV* -1 & $4.63 \%$ & $-0.48 \%$ & $10.39 \%$ & $-6.95 \%$ & $15.81 \%$ \\
\hline Offer price/NAV* ${ }^{*}-1$ & $-0.05 \%$ & $-1.80 \%$ & $6.54 \%$ & $-7.30 \%$ & $7.54 \%$ \\
\hline Midpoint/NAV* -1 & $0.03 \%$ & $-3.82 \%$ & $6.05 \%$ & $-9.88 \%$ & $10.93 \%$ \\
\hline Floor price/NAV* -1 & $-4.57 \%$ & $-7.16 \%$ & $1.72 \%$ & $-1.28 \%$ & $6.06 \%$ \\
\hline
\end{tabular}

Note: This table presents the mean values for the IPO for a sample of REITs listed in Asia between 2001 and 2013. In columns [1]-[3], the IPOs are partitioned into hot issue, normal issue and cold issue markets on the basis of the total volume of IPO issues in the respective markets from 2000 to 2013. Periods at the top quartile of the IPO volume are classified as hot issue markets, and those at the bottom $25 \%$ are classified as cold issue markets. In columns [4] and [5], IPOs are partitioned into popular and nonpopular IPO stocks on the basis of the market's reception to the individual offerings. Whenever the final offer price is higher than the midpoint of the book-building price range, the IPO is classified as a popular stock.

governance structure and/or attractive pricing of the shares. Therefore, we also separate the IPOs on the basis of the market's reception to the individual offering. Whenever the final offer price is higher (lower) than the midpoint of the book-building price range, the IPO is classified as a popular (unpopular) stock. Hanley (1993), Ritter (1998) and Aggarwal, Prabhala and Puri (2002) employ a similar approach to measure the popularity of individual IPOs.

Table 3 summarizes the IPO pricing range across different market conditions. First, it shows that the average initial day return is positive for the sample of IPOs issued in hot (4.68\%) and normal (3.18\%) markets and with popular IPOs $(6.89 \%)$, but is negative for IPOs issued in cold markets $(-1.33 \%)$ and with unpopular IPOs $(-4.09 \%)$. Second, the offer price is higher than the NAV in all market conditions even in cold markets (1.76\%), while the offer price is lower than the NAV with unpopular IPOs $(-2.16 \%)$. The results generally support that issuers set the offer price above their asset values regardless of the market condition, while the level of net gains of issuing 
firms is affected by the market condition. With unpopular IPOs, issuers suffer net losses if they choose to proceed with the IPO offerings.

The floor price is set close to the firm's NAV except in cold markets $(-3.08 \%)$ and with unpopular IPOs $(-3.57 \%)$. The first-day closing price is not too far from the $\mathrm{NAV}^{*}$ in hot $(2.39 \%)$ and normal $(1.12 \%)$ markets and with popular IPOs $(-0.50 \%)$, but it is much higher than the $\mathrm{NAV}^{*}$ in cold markets $(5.17 \%)$ and with unpopular IPOs (3.38\%). This result implies that, when the market condition is not supportive for IPOs and for the unpopular IPOs, the prevailing market premium might not contain useful information for IPO pricing, probably because these REITs are going public for unique reasons. It is also notable that the first-day closing price is, not surprisingly, much lower than the ceiling price in cold markets $(-4.13 \%)$ and with unpopular IPOs $(-10.42 \%)$.

Table 3 previously indicates that issuers generally priced the IPO stocks much higher than their fundamental values by timing the listings to avoid unfavorable conditions in the IPO market. To examine this trend further, Figure 2 tracks the NAV premium and the volume of REIT IPOs during the study period.

Chart A tracks the NAV premium and the volume of Asian REIT IPOs at the aggregate level, while Chart B tracks the NAV premium and the volume of all IPOs (including general stocks and REIT stocks) in each of the four markets. The two charts show that the trend of general stock IPOs generally mimics REIT IPOs in the Asian countries during the study period, with high IPO volumes during 2005-2007 and after 2012 and low IPO volumes during 2008-2009. Therefore, to define market conditions, we use IPO volumes of general stock markets to better capture the capital market conditions because the Asian REIT markets were nascent and thin during our study period.

The data also show a close linkage between IPO volume and stock market condition, indicative of issuers' practice of timing their IPO offerings when the underlying assets are more highly valued in the capital market than in the private market. The bullish valuation in the capital market helped issuers to price shares higher than the NAV and to achieve a final offer price that is at the top of the filing range. This market-timing behavior is consistent with the "windows of opportunity" hypothesis, whereby firms take advantage of transitory windows by issuing equity offerings when their stocks are substantially higher than the fundamental value of their underlying assets 
(Loughran and Ritter 1995, Buttimer, Hyland and Sanders 2005, Boudry, Kallberg and Liu 2010). ${ }^{24}$

To understand the determinants of the initial-day return and the long-run returns of individual IPOs, we run a set of regressions. The initial-day return is represented by the difference between the first-day closing price and the offer price of the shares, normalized by the offer price, while the long-run returns are represented by their buy-and-hold returns (BAHRs) for 100-day, one-year and three-year periods after the first trading day. This value is measured as the raw BAHR of the IPO stock minus the contemporaneous BAHR of the respective general stock market index. As previously noted, the initial-day return averaged $3.08 \%$. BAHRs are $-1.31 \%,-0.35 \%$ and $2.22 \%$ for 100-day, one-year and three-year periods, respectively.

Table 4 presents the definitions and summary statistics of the dependent and explanatory variables in the regression models. The key explanatory variable in our regression models is the offer price premium over the NAV $\left(O F F E R \_N A V\right)$. A positive relationship between OFFER NAV and the initialday return implies that, even with the IPO underpricing, issuers still gain from favorable valuations of the properties transferred to the newly listed REIT. However, we expect that the coefficients of OFFER_NAV in the longrun performance regression models to be negative as the bullish stock prices readjust back to their fundamental level.

To examine the pricing of new IPO firms relative to their peers, we also include the offer price premium over the peer-adjusted NAV (OFFER NAV*). A significant effect of $O F F E R \_N A V^{*}$ on the initial return would imply that the prevailing market premium contains relevant information that was not fully incorporated in the offer price. Also, as a proxy for quality and/or growth prospect, we expect $O F F E R \_N A V^{*}$ to have a direct relationship with the long-run performance of the individual IPOs. To account for the effects of market condition and market reception on the initial return and the long-run performance, we include variables for both hot and cold issuing markets and popularity of an IPO at the stock level. ${ }^{25}$

\footnotetext{
${ }^{24}$ As discussed earlier, Boudry, Kallberg and Liu (2010) find that REITs are more likely to issue seasoned equity offerings (SEOs) when their price/NAV is trading higher than 1 because, in this scenario, the cost of equity in the public market is cheaper than that in the private market. Buttimer, Hyland and Sanders (2005) similarly observe that REIT IPOs in the United States usually coincide with periods when REIT share prices were at a premium to their NAVs.

${ }^{25}$ As noted earlier, we identify popular IPOs by computing the percentage difference between the final offer price and the midpoint of the filing range of each IPO. Whenever the final offer price is higher than the midpoint of the book-building price range, the IPO is classified as a popular stock.
} 


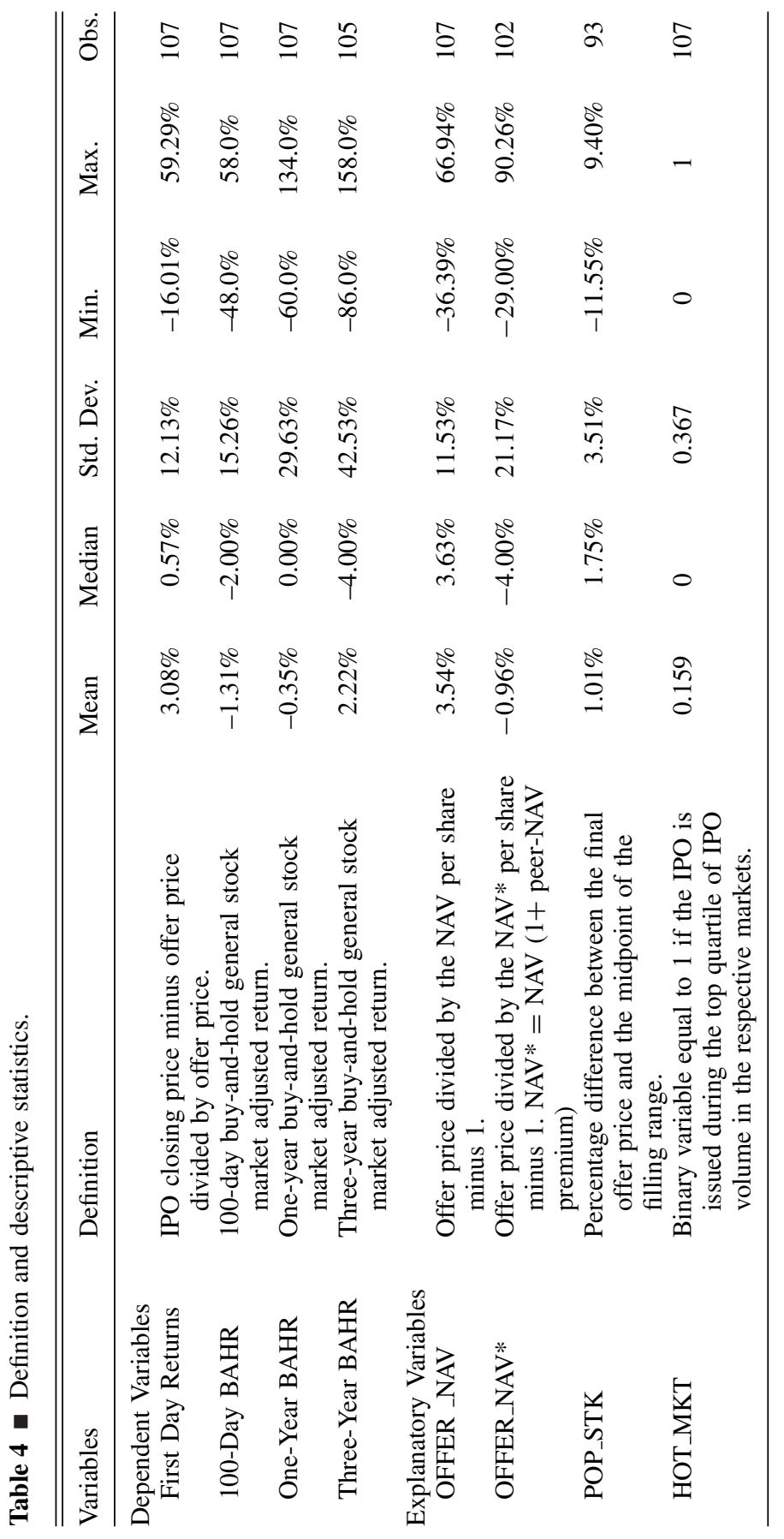




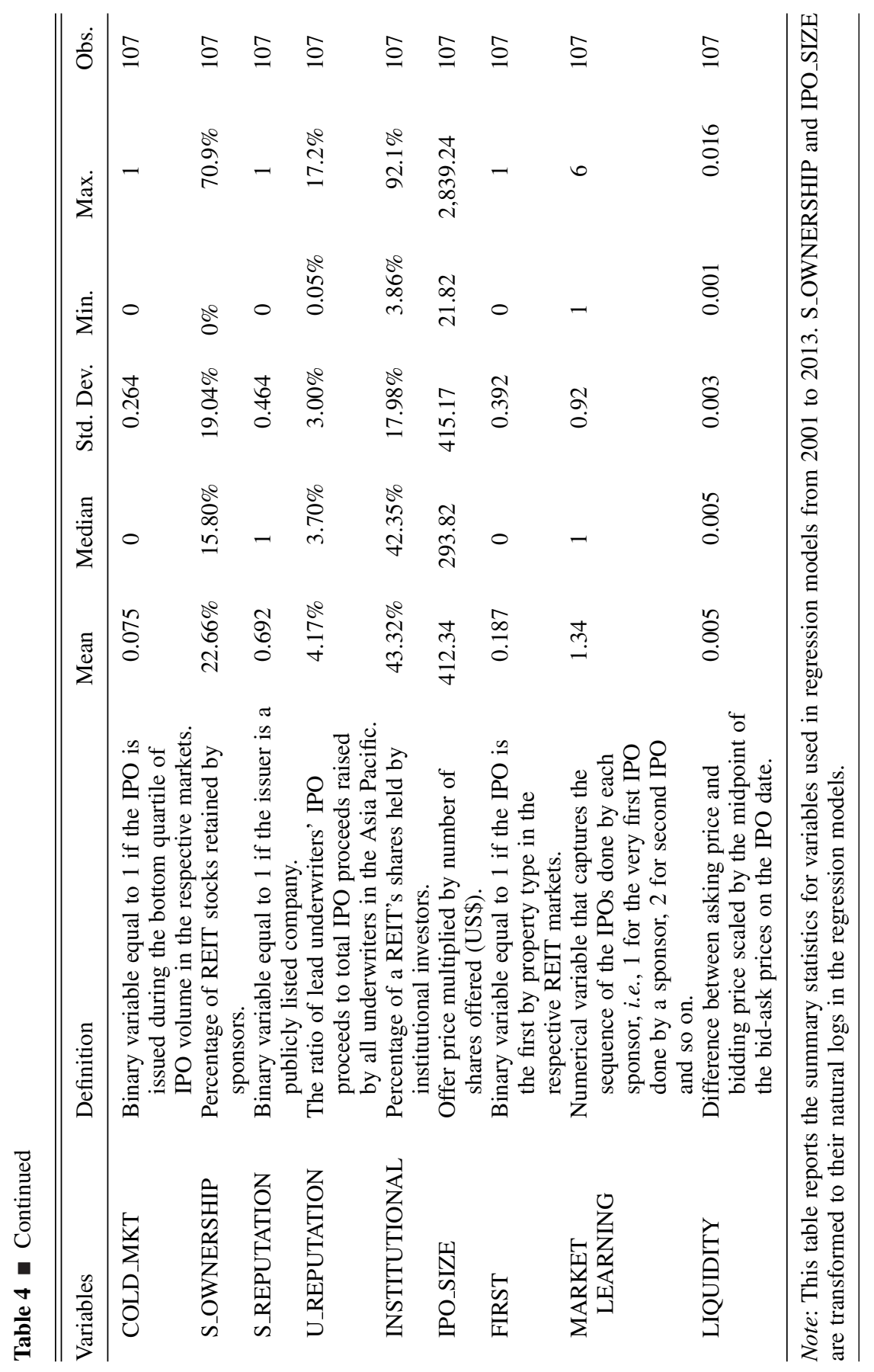


We also include a set of control variables in the regression models, namely, the sponsor's ownership (S_OWNERSHIP) and reputation (S_REPUTATION), the underwriter's reputation (U_REPUTATION), institutional holdings (INSTITUTIONAL) and issue size (IPO_SIZE). To control for scaling effects, natural logarithms are employed for $S_{-} O W N E R S H I P$ and IPO_SIZE. We also control for fixed effects related to property type and the market economy as well as a binary variable for maiden issue (FIRST) if the IPO is the first of a particular property type in the market economy. Kallberg, Liu and Srinivasan (2004) find that the quality of a real estate limited partnership decreases with each successive partnership issued by a given sponsor. To control for market learning in the initial return regressions, we created a numerical variable that captures the sequence of the IPOs done by each sponsor; e.g., this variable takes the value of 1 for the very first IPO done by a sponsor, 2 for the second IPO done by the same sponsor and so on (MARKET LEARNING). We control for liquidity (LIQUIDITY) in the initial return regressions using the bid-ask spread (the difference between the asking price and the bidding price scaled by the mid-price on the IPO date). ${ }^{26}$

Table 4 shows that the offer price premium over NAV averages $3.54 \%$. The IPO offer price was, on average, $1.01 \%$ higher than the midpoint of the book-building price range. The sponsors retained approximately $22.66 \%$ of the shares, which is comparable to post-IPO holdings of 23-26\% for venture capital sponsors (Barry et al. 1990, Megginson and Weiss 1991, Gompers and Lerner 1999). On average, institutional investors hold $43.32 \%$ of Asian REITs' stocks, which is close to the $44 \%$ observed by Hartzell, Kallberg and Liu (2008) for U.S. REIT IPOs. The average size of REIT IPOs is $\$ 412.3$ million, ranging from a minimum of $\$ 21.8$ million to a maximum of $\$ 2.84$ billion. In comparison, the average size of REIT IPOs in the United States ranges from $\$ 176$ million (Ling and Ryngaert 1997) to \$202 million (Gokkaya et al. 2015). Of the offerings, $15.9 \%$ (7.5\%) were issued during hot (cold) issue markets, respectively. The total number of IPOs performed by each sponsor ranges from 1 to 6 , with a mean value of 1.3 . The liquidity value of $0.5 \%$ represents the average bid-ask spread scaled by mid-price on IPO date. The magnitude of the variance inflation factor (VIF) ranges from 1.12 to 2.81 , indicating that multicollinearity is not a serious issue in the regression models.

\section{Determinants of Initial-Day Return}

Table 5 reports the estimation results for the initial day return. Model 1 is estimated using OLS. Because the amount of money left on the table is a

\footnotetext{
${ }^{26}$ Clayton and MacKinnon (2002) show that liquidity is a component of the NAV premium.
} 
Table 5 - Determinants of initial day return.

\begin{tabular}{|c|c|c|}
\hline & $\begin{array}{l}\text { Model } 1 \text { (OLS) } \\
\text { Initial Day Return }\end{array}$ & $\begin{array}{l}\text { Model } 2 \text { (2SLS) } \\
\text { Initial Day Return }\end{array}$ \\
\hline INTERCEPT & $\begin{array}{l}-0.03 \\
(-0.4)\end{array}$ & $\begin{array}{l}-0.10 \\
(-0.9)\end{array}$ \\
\hline OFFER_NAV & $\begin{array}{l}0.28^{*} \\
(1.8)\end{array}$ & $\begin{array}{l}0.26^{* *} \\
(2.1)\end{array}$ \\
\hline OFFER_NAV* & $\begin{array}{l}-0.07 \\
(-1.3)\end{array}$ & $\begin{array}{l}-0.03 \\
(-0.4)\end{array}$ \\
\hline POP_STK & $\begin{array}{l}1.36^{* * *} \\
(3.0)\end{array}$ & $\begin{array}{l}1.46^{* * *} \\
(3.4)\end{array}$ \\
\hline HOT_MKT & $\begin{array}{l}0.00 \\
(0.1)\end{array}$ & $\begin{array}{l}-0.01 \\
(-0.2)\end{array}$ \\
\hline COLD_MKT & $\begin{array}{l}-0.04 \\
(-1.6)\end{array}$ & $\begin{array}{l}-0.01 \\
(-0.2)\end{array}$ \\
\hline S_OWNERSHIP & $\begin{array}{l}0.60^{* *} \\
(2.3)\end{array}$ & $\begin{array}{l}2.52^{* * *} \\
(3.1)\end{array}$ \\
\hline S_REPUTATION & $\begin{array}{l}-0.02 \\
(-1.0)\end{array}$ & $\begin{array}{l}-0.06^{*} \\
(-1.8)\end{array}$ \\
\hline U_REPUTATION & $\begin{array}{l}-0.78 \\
(-1.6)\end{array}$ & $\begin{array}{l}-0.64 \\
(-1.3)\end{array}$ \\
\hline INSTITUTIONAL & $\begin{array}{c}0.10 \\
(1.6)\end{array}$ & $\begin{array}{l}0.35^{\text {*** }} \\
(2.8)\end{array}$ \\
\hline IPO_SIZE & $\begin{array}{l}-0.04 \\
(-1.0)\end{array}$ & $\begin{array}{l}-0.08^{*} \\
(-1.9)\end{array}$ \\
\hline FIRST & $\begin{array}{l}0.09^{* * * *} \\
(3.5)\end{array}$ & $\begin{array}{l}0.10^{* * *} \\
(2.9)\end{array}$ \\
\hline MARKET LEARNING & $\begin{array}{l}0.06^{* * * *} \\
(3.3)\end{array}$ & $\begin{array}{l}0.04^{* * *} \\
(2.8)\end{array}$ \\
\hline LIQUIDITY & $\begin{array}{l}-0.98 \\
(-0.3)\end{array}$ & $\begin{array}{l}9.53 \\
(1.4)\end{array}$ \\
\hline Country-fixed effects & Yes & Yes \\
\hline Property-type fixed effects & Yes & Yes \\
\hline \# of observations & 88 & 88 \\
\hline$R^{2}$ & 0.61 & 0.32 \\
\hline \multicolumn{3}{|c|}{$\begin{array}{l}\text { Note: This table reports estimates of the OLS (Model 1) and 2SLS (Model 2) regres- } \\
\text { sions to examine the determinants of the IPOs' initial-day return. The right-hand side } \\
\text { variables are defined in Table } 4 \text {. The instrument variable for the } 2 \text { SLS is firm size, } \\
\text { which is measured by the natural log of the REIT's market capitalization. } t \text {-Statistics } \\
\text { are reported in the parentheses with robust standard errors. } * * *, * * \text { and } * \text { refer to } \\
\text { statistical significance at the } 1 \%, 5 \% \text { and } 10 \% \text { levels, respectively. }\end{array}$} \\
\hline
\end{tabular}


function of two decisions, namely, the degree of underpricing and the number of shares sold (Loughran and Ritter 2002), the percentage of shares retained by the issuer (S_OWNERSHIP) might be endogenous in Model 1. As a robustness check, we reestimate the IPO underpricing and proportion of shares retained by the sponsors using a two-stage least squares (2SLS) IV regression that uses FIRM_SIZE (natural log of the market capitalization of individual REITs) as the instrument variable. The estimation involves regressing $S_{-}$OWNERSHIP against all covariates and the instrument variable and then using the predicted value of $S_{-} O W N E R S H I P$ to estimate the underpricing equation. The regression results are reported in Table 5 under Model $2 .{ }^{27}$ In each of the regressions, we also control for property- and country-fixed effects.

As predicted, the coefficient for $O F F E R \_N A V$ is positive and statistically significant in both models. This result is consistent with the hypothesis that an underpriced IPO can still generate a net gain for the issuing firm. Therefore, the average IPO creates wealth for both investors and issuers (refer also to Figure 1). The positive relation between OFFER_NAV and first-day returns indicates that when a larger net gain is targeted by the issuing firm, investors require higher initial returns too. OFFER_NAV*, on the other hand, is not significant, implying that there is no remaining information in the prevailing market premium that affects initial-day returns. This suggests that underwriters have incorporated useful information contained in the prevailing market premium in setting the offer price.

After controlling for the popularity of IPOs during the pre-market period (POP_STK), we find that the coefficients for HOT $\triangle K K T$ and $C O L D \_M K T$ are not statistically significant in explaining the initial-day return. ${ }^{28}$ The coefficient for POP_STK is positive and highly significant in both models. This is indicative of the effect of excess demand for shares spilling over to the secondary market; that is, investors who were not successful in the allocation exercise resorted to buying shares in the open market, and their actions increased the shares' first-day closing price. It is likely that IPO stocks that

\footnotetext{
${ }^{27}$ To derive consistent estimates, the instrument must fulfill two conditions: it must be uncorrelated with the error term, but is highly correlated with $S_{-} O W N E R S H I P$. In our case, the instrument variable is justified because its correlation with the error term is only 0.059 and statistically insignificant. The instrument variable also passed the standard diagnostic test for weak instruments; that is, the $F$-statistic of 11.646 is higher than the rule of thumb of 10 . For ease of exposition, the result of the 1st stage regression is not shown in Table 5. The significant variables in the 1st stage regression are S_REPUTATION, INSTITUTIONAL, IPO_SIZE, LIQUIDITY and FIRM_SIZE.
}

${ }^{28}$ Recall that hot (cold) IPO markets are classified as periods at the top (bottom) quartile of IPO volume in the year of the offering. Insignificant results remain when the cut-off point for defining hot (cold) markets is increased to $30 \%$ of the IPO volume. 
attract a high level of interest from institutional and retail investors leads to underwriters exercising the overallotment option. The regression results are robust when we redefine popular IPO stocks as offerings with an overallotment. ${ }^{29}$ In summary, Table 5 indicates that the market reception of individual IPO stocks has a significant influence on the initial-day return, while the prevailing market condition of the general IPO market does not.

The regression results also indicate that the number of shares retained by the issuers $\left(S_{-} O W N E R S H I P\right)$ plays a significant role in determining IPO underpricing. The positive coefficient indicates that issuers who sell proportionately fewer shares underprice the IPO to a greater degree. This is not surprising because issuers also stand to benefit from the initial price run-up on their retained shares (Loughran and Ritter 2002). The coefficient for INSTITUTIONAL has the predicted positive sign and is statistically significant in Model 2, which suggests that a greater degree of underpricing is required to entice institutional investors to buy IPO stocks. This is consistent with the winners' curse hypothesis that predicts a higher level of IPO underpricing in the presence of more institutional holdings. Meanwhile, the positive and significant coefficient for FIRST reflects the valuation uncertainty associated with the listing of pioneering REITs in the respective markets (Ling and Ryngaert 1997). ${ }^{30}$

While the underwriter's reputation (U_REPUTATION) does not impact the newly listed firm's initial performance, Model 2 shows that the issuer's reputation ( $S$ REPUTATION) has an inverse relationship with the degree of IPO underpricing. Market learning is surprisingly positive and significantly related to underpricing, implying that investors required higher discounts for the IPOs done by sponsors that experienced more previous REIT IPOs. This discount seems to represent a compensation for potential agency costs faced by a newly listed REIT, because its future property acquisitions and competition for tenants could be subordinated to existing REITs managed by the same sponsor. ${ }^{31}$ Liquidity does not affect initial returns beyond the effects of other variables.

\footnotetext{
${ }^{29}$ We could alternatively define POP_STK by the number of overallotment shares exercised divided by the total shares offered in the IPO. However, this identification strategy may cause an endogeneity problem because the overallotment option is exercised post-IPO.

${ }^{30} \mathrm{To}$ capture the potential effect of underpricing decreasing over time as investors become more familiar with the new product, we also substituted FIRST with the natural logarithm of the number of days since the first REIT in the market segment was listed (Ling and Ryngaert 1997). The results are qualitatively the same as for FIRST.

${ }^{31}$ This conflict of interest is evident especially among REITs in Asia that adopt the externally managed structure in which IPO sponsors continue providing assets and management services to their REITs after IPOs (Lecomte and Ooi 2013, Downs et al. 2016).
} 
In summary, we find that the initial-day return is positively related to the offer price premium to NAV and popularity of IPOs. Both the issuers and the investors gained from the IPO. Investors gained from the IPO underpricing, whereas issuers also gained from transferring the assets to a publicly listed entity at a premium to their intrinsic value.

\section{Determinants of Long-Run Performance}

Table 6 reports the estimation results for the long-run performance. As presented earlier, the long-run returns are represented by the individual REIT IPOs' BAHRs for the 100-day, one-year and three-year periods after the first trading day. This value is measured as the raw BAHR of the IPO stock minus the contemporaneous BAHR of the respective general stock market index. The BAHRs are measured against the general stock market index (left panel) and the REIT market (right panel) in the respective countries. Since the main results do not change greatly, we base our following discussions on the left panel of Table 6 .

As expected, OFFER $N A V$ has a significant negative effect on the one-year (Model 2) and the three-year (Model 3) long-run performance. While the negative effect is also observed for these IPO stocks for the 100-day horizon (Model 1), the coefficient is not significant. This is most likely due to the lockup period during which company insiders are not allowed to sell any of their shares. ${ }^{32}$ OFFER NAV* (the offer price premium over peer-adjusted NAV), on the other hand, shows strongly significant positive effects on the long-run performance against general stocks for all horizons (Models 1-3). A higher OFFER_NAV* indicates that the IPO REIT holds high-quality properties and or has better growth prospects compared to its peers. Thus, it is natural to observe better long-run performances with such IPO REITs.

The regression coefficients of POP_STK, HOT_MKT and COLD_MKT are statistically insignificant for the 100-day horizon (Model 1). HOT MKT shows a positive significant effect in Model 2, and POP_STK shows a positive significant effect in Model 3. These results suggest that stock popularity, bullish market condition and bearish market conditions during the offering do not have any effect on the short-run (100-day) underperformance of IPOs, while bullish market conditions and stock popularity affect the long-run performance over one-year or three-year horizons to some extent.

\footnotetext{
${ }^{32}$ The minimum lock-up period, typically 90 days, provides a commitment to the market that insiders will not immediately cash out their shareholdings following the IPO (see Chen, Chen and Huang 2012).
} 


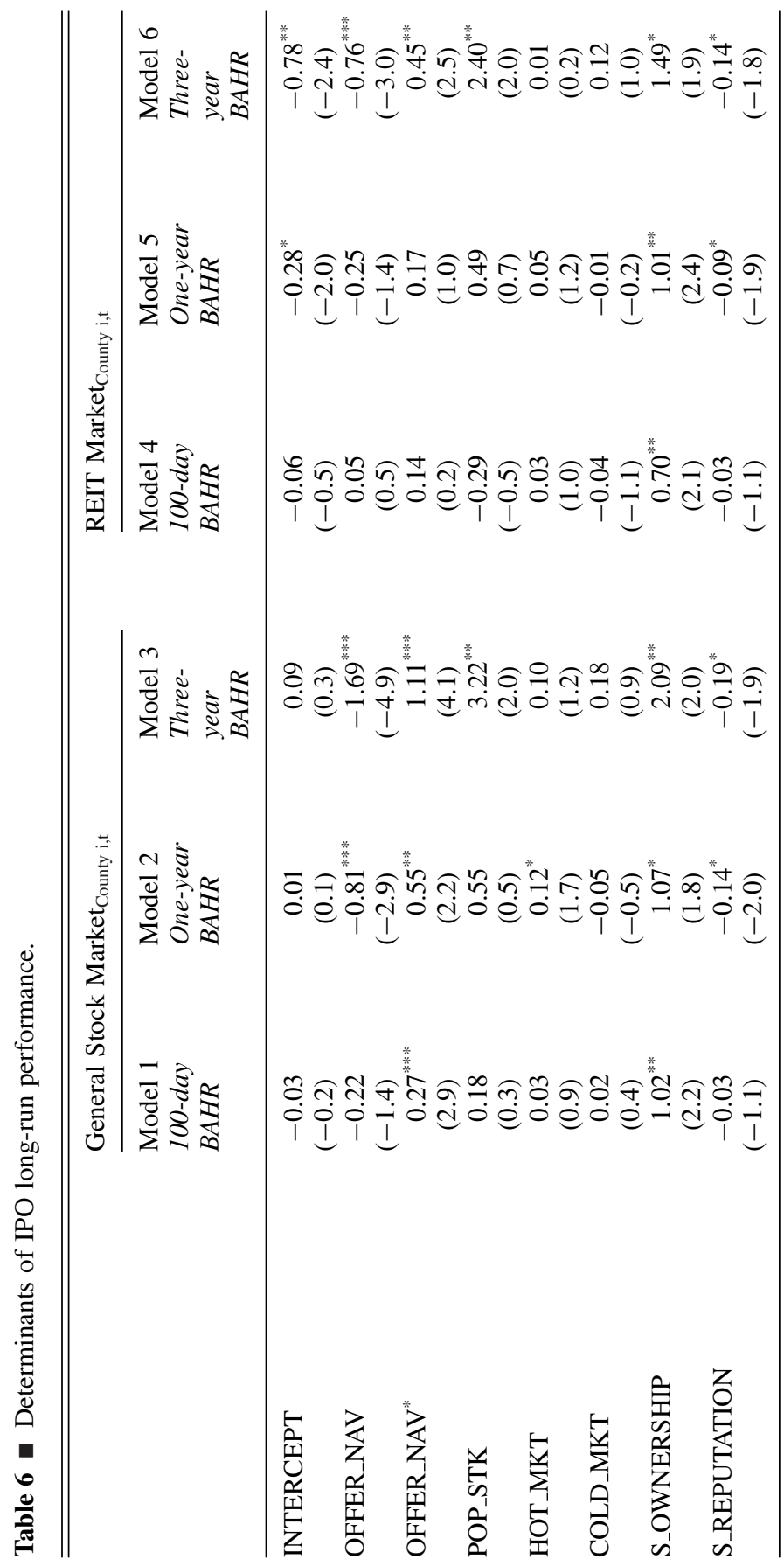




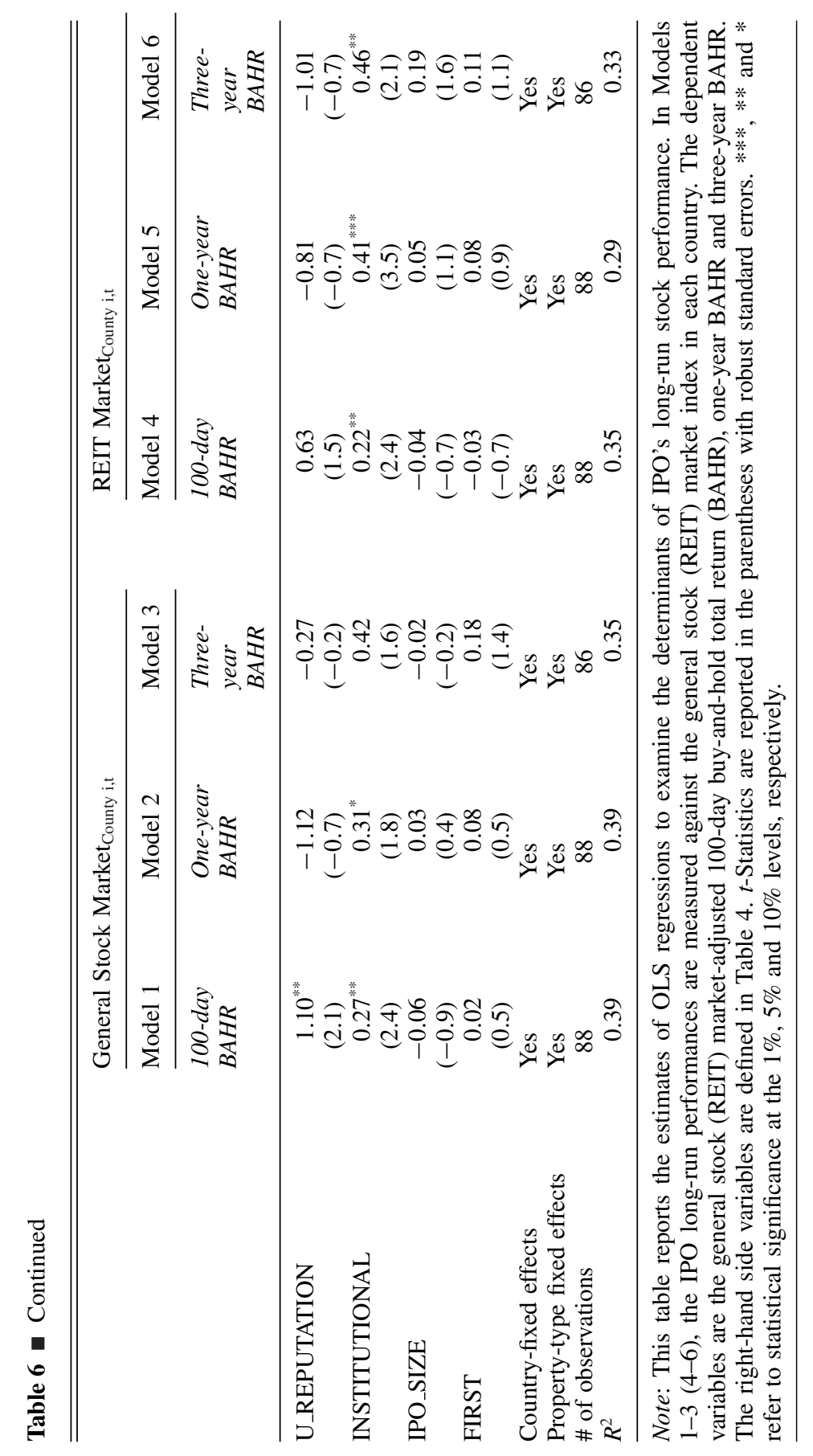


The proportion of shares retained by issuers $\left(S_{-}\right.$OWNERSHIP) and the proportion of shares allocated to institutional investors (INSTITUTIONAL) have positive impacts on stock underperformance that is observed during the first 100 days. Interestingly, the result shows that the stock performance of IPO REITs is negatively associated with the reputation of sponsors ( $\triangle \_$REPUTATION) for one-year and three-year horizons (Models 2 and 3).

\section{Conclusions}

The article examines issuers' rationale behind the IPO underpricing. We use a sample of REIT IPOs listed in four Asian markets (Malaysia, Japan, Hong Kong and Singapore) from 2001 to 2013, which offers a good indication of the listing firms' fundamental values. Several interesting observations are made. While the IPO underpricing is evident (3.1\%) with REIT IPOs, we find that issuers on average priced new issues $3.5 \%$ higher than their fundamental values measured by firms' NAVs. Thus, an IPO could be underpriced and yet produce a net gain for the issuer from IPO, which is why issuers can rationalize setting the offer price low relative to the first-day closing price. We also find that underwriters are generally careful enough to avoid missing an opportunity and incorporate the information contained in the market premium of the existing publicly traded REITs in setting IPO pricing. Several significant implications can be drawn from this study.

First, real estate owners can and do take advantage of "windows of opportunity" to divest asset holdings through the IPO route (instead of selling them directly in the private property market). Specifically, these owners favor the IPO route when more value can be extracted through the public market. This finding supports the IPO market-timing hypothesis (Baker and Wurgler 2002, Lowry 2003). ${ }^{33}$ Our results also offer an explanation to yet another puzzle in the IPO literature highlighted by Ritter and Welch (2002), which is why the volume declines precipitously following a stock market decline. In a cold IPO market, there is a quantity adjustment (that is, the number of IPOs declines) rather than a price adjustment, because the issuer has to sell shares below the NAV. Issuers who are averse to registering any net loss have the options of either selling their assets in the private market or deferring the offering to another time.

Second, our investigation shows that the IPO underpricing is mostly a product of frothiness attributable to excess demand in the IPO market. Although the

\footnotetext{
${ }^{33}$ Previous studies by Lerner (1994) and Pagano and Zingales (1998) also show that the industry's high market-to-book ratios have a substantial effect on the firm's decision to go public.
} 
issuers could have exploited the situation by fully skimming the froth, the evidence suggests that they do not. Because the offer price is already higher than the intrinsic value of the assets (that is, what the assets could have fetched if they had been sold in the private property market), issuers price the shares slightly lower than their peers. Our main finding that IPOs can be underpriced but represent a net gain for the issuing firm calls for alternative methods of measuring the fundamental value for non-REIT new firms. Given that issuers of non-REIT firms do leave money on the table, it is plausible to expect that the IPOs of general stocks may also be priced higher than their fundamental values, if measured correctly.

We thank Brent Ambrose, Zhi Dong, Mike Highfield, Jarl Kallberg, H.C. $\mathrm{Su}$, Tim Riddiough, Jay Ritter, Mo Rodriguez, S.E. Ong, Jim Shilling and the Fellows of the Weimer School of Advanced Studies in Real Estate and Land Economics at the January 2017 meeting for their helpful comments on previous drafts of this article. The comments of two anonymous referees and Jon Wiley (the Editor) helped to substantially improve this article.

\section{References}

Aggarwal, R., N.R. Prabhala and M. Puri. 2002. Institutional Allocation in Initial Public Offerings: Empirical Evidence. Journal of Finance 57: 1421-1442.

Allen, F. and G.R. Faulhaber. 1989. Signaling by Underpricing in the IPO Market. Journal of Financial Economics 23: 303-323.

Baker, M. and J. Wurgler. 2002. Market Timing and Capital Structure. Journal of Finance 57: 1-32. and 2006. Investor Sentiment and the Cross-Section of Stock Returns. Journal of Finance 61: 1645-1680.

Barkham, R.J. and C.W. Ward. 1999. Investor Sentiment and Noise Traders: Discount to Net Asset Value in Listed Property Companies in the U.K. Journal of Real Estate Research 18: 291-312.

Barry, C.B., C.J. Muscarella, J.W. Peavy and M.R. Vetstuypens. 1990. The Role of Venture Capital in the Creation of Public Companies: Evidence from the Going-Public Process. Journal of Financial Economics 27: 447-471.

Below, S., M.A. Zaman and W. McIntosh. 1995. The Pricing of Real Estate Investment Trust Initial Public Offerings. The Journal of Real Estate Finance and Economics 11: $55-64$.

Benveniste, L.M. and P.A. Spindt. 1989. How Investment Bankers Determine the Offer Price and Allocation of New Issues. Journal of Financial Economics 24: 343-361.

Boudry, W.L., J.G. Kallberg and C.H. Liu. 2010. An Analysis of REIT Security Issuance Decisions. Real Estate Economics 38: 91-120.

Brounen, D. and P. Eichholtz. 2002. Initial Public Offerings: Evidence from the British, French and Swedish Property Share Markets. Journal of Real Estate Finance and Economics 24: 103-117.

Buttimer, R.J., D.C. Hyland and A.B. Sanders. 2005. REITs, IPO Waves and LongRun Performance. Real Estate Economics 33: 51-87. 
Campbell, C.J., Y. Du, S.G. Rhee and N. Tang. 2008. Market Sentiment, IPO Underpricing, and Valuation. Working Paper, Iowa State University, Barclays Global Investors, University of Hawaii and Wilfrid Laurier University.

Capozza, D.R. and P.J. Seguin. 2003. Inside Ownership, Risk Sharing and Tobin's Q Ratio: Evidence from REITs. Real Estate Economics 31: 367-404.

Chan, S.H., J. Chen and K. Wang. 2013. Are REIT IPOs Unique? The Global Evidence. Journal of Real Estate Finance and Economics 47: 719-759.

, K. Wang and J. Yang. 2009. IPO Pricing Strategies with Deadweight and Search Costs. Journal of Real Estate Research 31(4): 481-542.

Chen, H.C., S.S. Chen and C.W. Huang. 2012. Why Do Insiders Sell Shares Following IPO Lockups? Financial Management 41(4): 813-847.

Cherkes, M., J.S. Sagi and R. Stanton. 2009 A Liquidity-Based Theory of Closed-End Funds. The Review of Financial Studies 22(1): 257-297.

Clayton, J. and G. MacKinnon. 2000. Explaining the Discount to NAV in REIT Pricing: Noise or Information? Working Paper, University of Connecticut, Saint Mary's University.

and - 2002. Departures from NAV in REIT Pricing: The Private Real

Estate Cycle, the Value of Liquidity and Investor Sentiment. Working Paper, Real Estate Research Institute.

Daniel, K., D. Hirshleifer and A. Subrahmanyam. 1998. Investor Psychology and Security Market Under-and Overreactions. Journal of Finance 53: 1839-1884.

Degeorge, F., F. Derrien and K.W. Womack. 2007. Analyst Hype in IPOs: Explaining the Popularity of Book-building. Review of Financial Studies 20(4): 1021-1058.

Derrien, F. 2005. IPO Pricing in "Hot" Market Conditions: Who Leaves Money on the Table? Journal of Finance 60: 487-521.

Downs, H.D., J.T.L. Ooi, W.C. Wong and S.E. Ong. 2016. Related Party Transactions and Firm Value: Evidence from Property Markets in Hong Kong, Malaysia and Singapore. Journal of Real Estate Finance and Economics 52: 408-427.

Gentry, W.M., C.M. Jones and J.C. Mayer. 2003. What Can We Learn about the Sensitivity of Investment to Stock Prices with a Better Measure of Tobin's Q? Working Paper, Columbia University.

- $\longrightarrow$ and 2004. Do Stock Prices Really Reflect Fundamental Values? The Case of REITs. Working Paper, National Bureau of Economic Research. Gokkaya, S., M.J. Highfield, K.D. Roskelley and D.F. Steele. 2015. An Examination of Primary and Secondary Market Returns in Equity REIT IPOs. Journal of Real Estate Research 37: 23-64.

Gompers, P.A. and J. Lerner. 1999. Conflict of Interest in the Issuance of Public Securities: Evidence from Venture Capital. Journal of Law and Economics 42: 1-28.

Grinblatt, M. and C.Y. Hwang. 1989. Signaling and the Pricing of New Issues. Journal of Finance 44: 393-420.

Habib, M.A. and A. Ljungqvist. 2001. Underpricing and Entrepreneurial Wealth Losses in IPOs: Theory and Evidence. Review of Financial Studies 14, 433458.

Hanley, K.W. 1993. The Underpricing of Initial Public Offerings and the Partial Adjustment Phenomenon. Journal of Financial Economics 34: 231-250.

Hartzell, J.C., J.G. Kallberg and C.H. Liu. 2005. The Role of the Underlying Real Estate Market in REIT IPOs. Real Estate Economics 33: 27-50.

— $\longrightarrow$ and 2008. The Role of Corporate Governance in Initial Public Offerings: Evidence from Real Estate Investment Trusts. Journal of Law and Economics 51: 539-561. 
Jagannathan, R. and Y. Gao. 2004. Are IPOs Underpriced? A Closer Examination. Working Paper, Northwestern University and California State University at Los Angeles.

Kallberg, J.G., C.H. Liu and A. Srinivasan. 2004. Limited Partnerships and Reputation Formation. Journal of Financial and Quantitative Analysis 39: 631-659.

Kim, M. and J.R. Ritter. 1999. Valuing IPOs. Journal of Financial Economics 53: 409-437.

Lecomte, P. and J.T.L. Ooi. 2013. Corporate Governance and Performance of Externally Managed Singapore REITs. Journal of Real Estate Finance and Economics 46: 664-684.

Lee, C., A. Shleifer and R.H. Thaler. 1991. Investor Sentiment and the Closed-end Fund Puzzle. Journal of Finance 46:75-109.

Lerner, J. 1994. Venture Capitalists and the Decision to Go Public. Journal of Financial Economics 35: 293-316.

Ling, D.C., J.T.L. Ooi and R. Xu. 2016. Asset Growth and Stock Performance: Evidence from REITs. Real Estate Economics, forthcoming. https://doi.org/10.1111/ 1540-6229.12186

and M. Ryngaert. 1997. Valuation Uncertainty, Institutional Involvement, and the Underpricing of IPOs: The Case of REITs. Journal of Financial Economics 43: 433-456.

Liow, K.H. 2003. Property Company Stock Price and Net Asset Value: A Mean Reversion Perspective. Journal of Real Estate Finance and Economics 27: 235-255.

Liu, X. and J. Ritter. 2011. Local Underwriter Oligopolies and IPO Underpricing, Journal of Financial Economics 102: 579-601.

Ljungqvist, A. 2008. IPO Underpricing. In Handbook of Corporate Finance: Empirical Corporate Finance, Vol. 1. B.E. Eckbo, ed. New York: Elsevier B.V.

Loughran, T. and J.R. Ritter. 1995. The New Issues Puzzle. Journal of Finance 50: $23-51$.

2002. Why Don't Issuers Get Upset About Leaving Money on the Table on IPOs? Review of Financial Studies 15: 413-443.

, and K. Rydqvist. 2017. Initial Public Offerings: International Insights. Published in the June 1994 Pacific-Basin Finance Journal 2: 165-199. Updated October 9, 2017 on Jay Ritter's website.

Lowry, M. 2003. Why Does IPO Volume Fluctuate So Much? Journal of Financial Economics 67: 3-40.

and S. Shu. 2002. Litigation Risk and IPO Underpricing. Journal of Financial Economics 65: 309-335.

Megginson, W.L. and K.A. Weiss. 1991. Venture Capitalist Certification in Initial Public Offerings. Journal of Finance 46: 879-903.

Miller, E.M. 1977. Risk, Uncertainty, and Divergence of Opinion. Journal of Finance 32: 1151-1168.

NACVA. 2012. Chapter Six: Commonly Used Methods of Valuation. In Fundamentals, Techniques and Theory. Available at: http://edu.nacva.com/ preread/2012BVTC/2012v1_FTT_Chapter_Six.pdf

Ooi, J.T.L. 2009. The Compensation Structure of REIT Managers: Impact on Stock Valuation and Performance. Journal of Property Research 26: 309-328.

S.E. Ong and L. Li. 2010. An Analysis of the Financing Decisions of REITs: The Role of Market Timing and Target Leverage. Journal of Real Estate Finance and Economics 40: 130-160. 
Pagano, M.F.P. and L. Zingales. 1998. Why Do Companies Go Public? An Empirical Analysis. Journal of Finance 53: 27-64.

Patel, K., R.A.M.G. Pereira, and K.V. Zavodov. 2009. Mean-Reversion in REITs Discount to NAV \& Risk Premium. Journal of Real Estate Finance and Economics 39: 229-247.

Peavy III, J.W. 1990. Returns on Initial Public Offerings of Closed-End Funds. Review of Financial Studies 3: 695-708.

Pukthuanthong-Le, K. and N. Varaiya. 2007. IPO Pricing, Block Sales, and Long-Term Performance. The Financial Review 42: 319-348.

Purnanandam, A.K. and B. Swaminathan. 2004. Are IPOs Really Underpriced? The Review of Financial Studies 17: 811-848.

Ritter, J. 1998. Initial Public Offerings. Contemporary Finance Digest 2: 5-30.

Ritter, J.R. and I. Welch. 2002. A Review of IPO Activity, Pricing, and Allocation. Journal of Finance 57: 1795-1828.

Rock, K. 1986. Why New Issues are Underpriced. Journal of Financial Economics 15: $187-212$.

Tinic, S.M. 1988. Anatomy of Initial Public Offerings of Common Stock. Journal of Finance 43: 789-822.

Wang, K., S.H. Chan and G.W. Gau. 1992. Initial Public Offerings of Equity Securities: Anomalous Evidence Using REITs. Journal of Financial Economics 31: 381-410.

Wong, W.C., S.E. Ong and J.T.L. Ooi. 2013. Sponsor Backing in Asian REIT IPOs. Journal of Real Estate Finance and Economics 46: 299-320. 


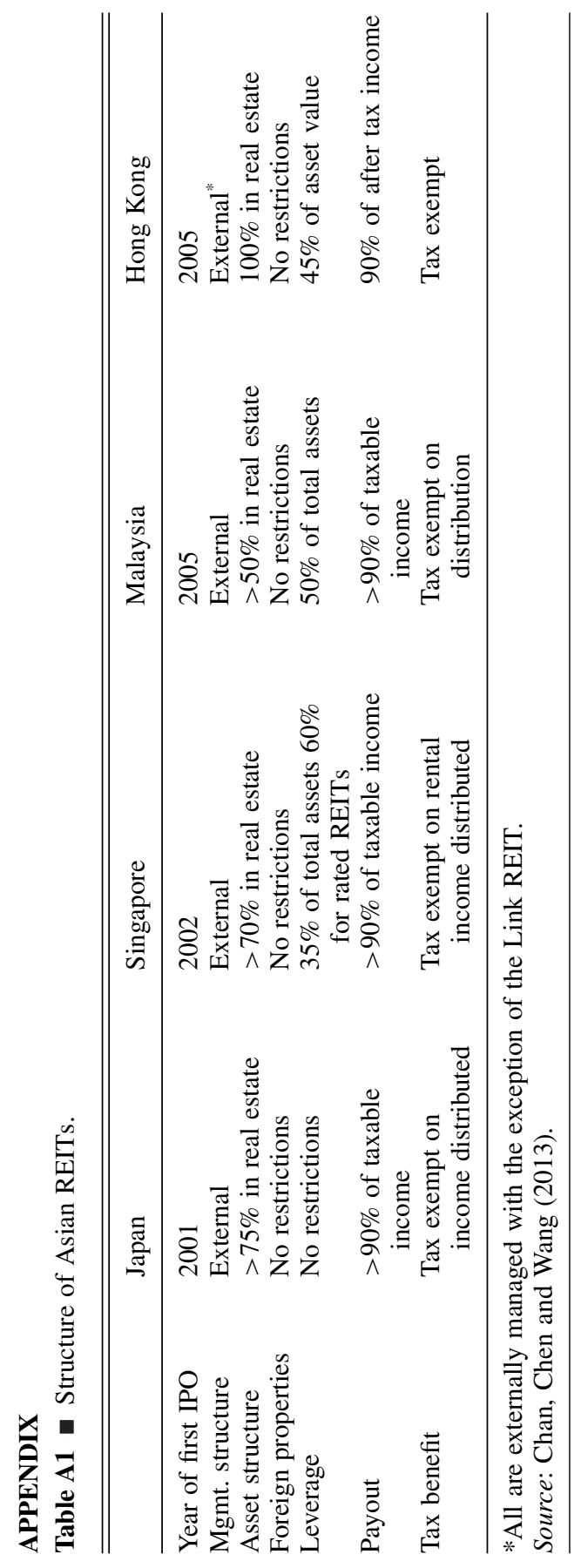

